\title{
PENGELOLAAN KREDIT PADA \\ PT. BANK PERKREDITAN RAKYAT \\ RANGKIANG AUR
}

\author{
Dolla Sriwati, Mariani St.B Tanjung \\ Akademi Keuangan dan Perbankan Padang \\ mstbtanjung@gmail.com
}

\begin{abstract}
ABSTRAK
Penelitian ini bertujuan untuk mengetahui sumber dana diperoleh untuk pemberian kredit, prosedur dan pelaksanaan pemberian kredit, kebijaksanaan yang diambil dalam mengatasi hambatan penarikan kredit. Dalam menganalisa data, penulis menggunakan metode analisa data kualitatif. Metode analisa data kualitatif ini digunakan sebagai metode penelitian yang menjelaskan secara deskriptif mengenai prosedur dalam kegiatan pamberian kredit pada PT. Bank Perkreditan Rakyat Rangkiang Aur. Peningkatan peranan perbankan sangat diperlukan untuk meningkatkan volume usaha rill yang dapat mendorong pertumbuhan ekonomi dan dapat meningkatkan kesejahteraan masyarakat. PT. BPR Rangkiang Aur adalah lembaga yang berkompeten untuk mewujudkan peningkatan pertumbuhan perekonomian khususnya masyarakat dalam strata menengah ke bawah. Terbukti dengan peningkatan volume usaha, penyaluran di bidang kredit dan kualitas dari kredit yang disalurkan.
\end{abstract}

Kata Kunci: Kredit, Bank Perkreditan Rakyat

\section{LATAR BELAKANG}

Sejak berlakunya Undang - Undang No. 7 Tahun 1992 dan telah diperbaharui menjadi Undang - Undang No. 10 Tahun 1998, jenis bank yang diakui secara resmi hanya terdiri dari 2 ( dua ) jenis yaitu Bank Umum dan Bank Perkreditan Rakyat. Perbedaan BPR dengan Bank Umum adalah kegiatannya lebih terbatas dan tidak boleh menerima simpanan dalam bentuk giro,ikut kliring dan melaksanakan transaksi valuta asing, serta tidak menyediakan jasa dalam lalu lintas pembayaran.

Bank Perkreditan Rakyat didefenisikan oleh Undang - Undang No 10 tahun 1998 tentang Perbankan sebagai berikut : "Bank Perkreditan Rakyat adalah Bank yang melaksanakan kegiatan usahanya secara konvensional atau berdasarkan prinsip syariah yang dalam kegiatannya tidak memberikan jasa dalam lalu lintas pembayaran".

Sebagai salah satu lembaga keuangan yang ada di tingkat masyarakat pedesaan, BPR memiliki peran yang sangat besar dalam menunjang perekonomian masyarakat. Hal itu disadari karena sampai saat ini tidak ada lembaga keuangan secara khusus mengkonsentrasikan diri kepada permodalan usaha masyarakat menengah ke bawah. 
Salah satu fungsi utama bank adalah sebagai lembaga perantara (intermediary) antara masyarakat yang kelebihan dana dengan masyarakat yang membutuhkan dana (defisit unit), dan keuntungan bank diperoleh dari selisih harga jual dan harga beli dana tersebut dikurangi dengan biaya operasional. Dengan demikian bank harus mampu menempatkan dana yang telah dihimpun dalam bentuk penempatan yang paling menguntungkan yaitu dalam bentuk kredit.

Berdasarkan Undang - Undang No. 10 Tahun 1998 tentang Perbankan, kredit adalah penyediaan uang atau tagihan yang dapat dipersamakan dengan itu, berdasarkan persetujuan atau kesepakatan pinjam meminjam antara bank dengan pihak lain yang mewajibkan pihak peminjam untuk melunasi hutangnya setelah jangka waktu tertentu dengan pemberian bunga.

Bank Perkreditan Rakyat ( BPR ) Rangkiang Aur sebagai lembaga yang fokus terhadap pelayanan transaksi ekonomi masyarakat menengah ke bawah, terutama pada para pedagang kecil yang berada di kawasan Aur Bukittinggi. Karena itu PT. BPR Rangkiang Aur terus berusaha meningkatkan kualitas modal dan sumber daya manusia, mendorong pembangunan ekonomi melalui menghimpun dana yang terarah dengan produk tabungan dan deposito serta berusaha membantu pengembangan usaha kecil dan mikro melalui pemberian kredit.

Sebagai lembaga yang memberikan fasilitas kredit maka PT. BPR Rangkiang Aur akan memperoleh pendapatan utama berupa bunga kredit dan pendapatan lainnya dengan segala konsekuensinya akan menanggung berbagai resiko, artinya bank menderita kerugian jika fasilitas yang telah dinikmati oleh debitur tidak dapat diterima kembali oleh bank tepat pada jatuh tempo nya. Oleh karena itu bank membutuhkan berbagai kebijaksanaan dalam penyaluran perkreditan serta berusaha mengurangi resiko kredit seperti mengasuransikan kredit tersebut pada pihak asuransi dan analisa yang cermat terhadap calon debitur sebelum kredit dicairkan dan pengawasan kredit yang telah direalisasikan.

Untuk itu penulis tertarik untuk meneliti proses persetujuan kredit dan menggambarkan pemberian kredit yang disalurkan dengan judul : "Pengelolaan Kredit Pada PT. Bank Perkreditan Rakyat Rangkiang Aur”.

Perumusan Masalah

Sesuai dengan judul laporan, maka masalah yang dibahas dalam laporan penelitian ini dirumuskan sebagai berikut :

1. Darimana sumber dana diperoleh untuk pemberian kredit.?

2. Bagaimana prosedur dan pelaksanaan pemberian kredit.?

3. Kebijaksanaan apa yang diambil dalam mengatasi hambatan penarikan kredit.?

\section{METODE PENELITIAN}

Di dalam melakukan penelitian ini akan digunakan metode - metode pengumpulan data, sebagai berikut :

Metode Pengumpulan Data

1. Studi Pustaka (Library Research)

Penelitian ini dilakukan dengan cara mempelajari buku-buku bacaan laporan-laporan dan publikasi yang berhubungan dengan objek penelitian. 


\section{Studi Lapangan (Field Research)}

Penelitian yang langsung dilakukan ke lapangan yaitu pada PT. Bank Perkreditan Rakyat Rangkiang Aur untuk memperoleh data yang diperlukan dan melakukan wawancara untuk mendapatkan data primer.

Metode Analisa Data

Dalam menganalisa data, penulis menggunakan metode analisa data kualitatif. Metode analisa data kualitatif ini digunakan sebagai metode penelitian yang menjelaskan secara deskriptif mengenai prosedur dalam kegiatan pamberian kredit pada PT. Bank Perkreditan Rakyat Rangkiang Aur.

\section{LANDASAN TEORI}

\section{Pengertian Bank}

Menurut Undang - Undang Perbankan No. 10 Tahun 1998, bank adalah badan usaha yang menghimpun dana dari masyarakat dalam bentuk simpanan dan menyalurkannya kepada masyarakat dalam bentuk kredit dan atau bentuk lain dalam rangka meningkatkan taraf hidup rakyat banyak.

Bank di Indonesia terdiri atas :

1. Bank Umum

Yaitu bank yang melaksanakan kegiatan usaha secara konvensional dan atau berdasarkan prinsip syariah yang dalam kegiatannya memberikan jasa dalam lalu lintas pembayaran.

2. Bank Perkreditan Rakyat ( BPR )

Yaitu bank yang melaksanakan kegiatan usaha secara konvensional atau berdasarkan prinsip syariah yang dalam kegiatannya tidak memberikan jasa dalam lalu lintas pembayaran.

Fungsi dan Jenis - Jenis Bank

Fungsi bank yaitu sebagai penghubung (intermediary) antara pihak yang kelebihan dana ( surplus) dan pihak yang kekurangan dana (defisit) dan sebagai jasa keuangan perbankan.

Jenis bank berdasarkan sifatnya terdiri dari :

1. Bank Devisa

Merupakan bank yang dapat melaksanakan transaksi keluar negeri atau yang berhubungan dengan mata uang asing secara keseluruhan, misalnya transfer keluar negeri, inkaso keluar negeri, travelers cheque, pembukaan dan pembayaran Letter of Credit dan transaksi lainnya.

2. Bank Non Devisa

Merupakan bank yang belum mempunyai izin untuk melaksanakan transaksi sebagai bank devisa, sehingga tidak dapat melaksanakan transaksi seperti halnya bank devisa, dimana transaksi yang dilakukan masih dalam batas - batas negara.

Sumber - Sumber Dana Bank

Yang dimaksud dengan sumber-sumber dana bank adalah usaha bank dalam menghimpun dana untuk membiayai operasinya. Asal dana yaitu bersumber dari bank itu sendiri, yang didapat dari setoran modal pemegang saham dan laba pada tahun lalu yang tidak dibagi kepada pemegang sahamnya. 
Asal dana berikutnya didapat dari pihak ketiga yaitu berupa tabungan, deposito, giro dan berasal dari lembaga lainnya yaitu pinjaman antar bank, pinjaman bank - bank luar negeri kredit likuiditas Bank Indonesia dan Surat Berharga Pasar Uang (SBPU).

Kegiatan - Kegiatan Bank

Kegiatan Bank Umum yaitu menghimpun dana masyarakat ( funding ), menyalurkan dana ke masyarakat ( lending ), dan memberikan jasa-jasa bank lainnya ( service).

Kegiatan Bank Perkreditan Rakyat yaitu menghimpun dana dalam bentuk simpanan tabungan dan simpanan deposito, menyalurkan dana dalam bentuk kredit investasi, kredit modal kerja dan kredit perdagangan.

Adapun larangan bagi Bank Perkreditan Rakyat yaitu tidak menerima simpanan giro, tidak mengikuti kegiatan kliring, tidak boleh melakukan transaksi valuta asing dan tidak boleh melakukan kegiatan perasuransian.

Pengertian Kredit

Istilah Credit, berasal dari perkataan latin Credo, yang berarti I Believe, I Trust, saya percaya atau saya menaruh kepercayaan. Apabila seorang ingin memperoleh kredit, hal yang paling essential yang harus dipenuhi adalah rasa percaya. Dari rasa percaya tersebut maka timbullah sebuah perjanjian kredit antar si penerima kredit ( Debitur ) dengan si pemberi kredit ( Kreditur ) yang menyepakati sejumlah pinjaman dengan syarat pengembalian menurut jangka waktu yang telah disepakati dan imbalan yang disetujui bersama.

Menurut Sinungan, mengatakan bahwa kredit adalah suatu pemberian prestasi oleh suatu pihak kepada pihak lain dan prestasi itu akan dikembalikan lagi pada suatu masa yang akan datang disertai dengan suatu kontra prestasi berupa bunga.

Sedangkan, berdasarkan Undang - Undang No. 7 tahun 1992 dan telah diperbaharui manjadi Undang - Undang No. 10 Tahun 1998 pasal 1 ayat 11 tentang perbankan menyatakan kredit adalah penyediaan uang atau tagihan yang dapat dipersamakan dengan itu, berdasarkan persetujuan atau yang mewajibkan pinjam meminjam antara bank dengan pihak lain yang mewajibkan pihak peminjam untuk melunasi hutangnya setelah jangka waktu dengan jumlah bunga, imbalan atau pembagian hasil keuntungan.

Menurut Z. Dunil dalam Standar Akuntansi Keuangan khususnya dalam PSAK No. 31 yang dimaksud dengan kredit yang diberikan dalam penyediaan uang atau tagihan yang dapat dipersamakan dengan itu. Berdasarkan persetujuan atau kesepakatan pinjam meminjam antara bank dengan pihak lain yang mewajibkan pihak peminjam untuk melunasi hutangnya setelah jangka waktu tertentu dengan jumlah bunga imbalan atau pembagian hasil keuntungan. Termasuk dalam pengertian kredit yang diberikan adalah pembiayaan bersama dan kredit dalam proses penyelamatan.

Dari pengertian di atas, terdapat dua pihak secara langsung berkaitan dalam proses pemberian kredit. Yang pertama, pihak pemberi kredit ( Kreditur ) yaitu pihak yang mempunyai kelebihan dana dan pihak penerima kredit ( Debitur ) yaitu pihak yang membutuhkan dana. Disini terlihat fungsi bank sebagai lembaga perantara antara pihak yang mempunyai dana lebih dan butuh rasa aman terhadap uang yang dimilikinya dengan pihak yang sangat 
membutuhkan dana untuk membuka usaha baru atau pun melanjutkan usaha yang telah dijalaninya.

Bank merupakan lembaga financial intermediary berperan aktif sebagai perantara dari kedua belah pihak tersebut. Bank menghimpun dana dari masyarakat yang kelebihan dana dalam bentuk simpanan dan kemudian menyalurkannya kembali kepada masyarakat dalam bentuk kredit atau yang dipersamakan dengan itu secara efektif kepada melalui sektor usaha yang produktif. Sebagai lembaga perantara, bank diharapkan mampu turut serta meningkatkan taraf kehidupan masyarakat secara khusus dan peningkatan perekonomian secara umum.

Fungsi Dan Tujuan Pemberian Kredit

Fungsi kredit perbankan dalam kehidupan perekonomian dan perdagangan antara lain sebagai berikut :

- Kredit pada hakekatnya dapat meningkatkan daya guna uang.

- Kredit dapat meningkatkan peredaran dan lalu lintas uang.

- Kredit dapat meningkatkan daya guna dan peredaran barang.

- Kredit sebagai salah satu alat kebijakan pemerintah untuk stabilisasi perekonomian.

- Kredit dapat meningkatkan kegairahan usaha.

- Kredit dapat meningkatkan pemerataan pendapatan. Tujuan pokok dari pemberian kredit oleh suatu bank adalah untuk :

- Turut mensukseskan program pemerintah dibidang ekonomi dan pembangunan.

- Meningkatkan aktivitas ekonomi atau kegiatan perusahaan agar dapat menjalankan fungsinya guna menjamin terpenuhinya kebutuhan masyarakat.

- Memperoleh laba agar kelangsungan hidup bank dapat terjamin, mengingat pemberian kredit merupakan kegiatan utama bank dan penghasilan pokok bank.

Tetapi pada dasarnya tujuan pemberian kredit yaitu terdiri dari :

- Mencari keuntungan

- Membantu usaha nasabah

- Membantu pemerintah

Unsur-unsur dan Jenis-jenis Kredit

Unsur-unsur yang terdapat dalam kredit, menurut Suyanto dkk (1995:14), antara lain :

a. Kepercayaan (Trust)

Yaitu keyakinan si pemberi kredit bahwa prestasi yang diberikannya baik dalam bentuk uang, barang, atau jasa akan benar - benar diterimanya kembali dalam jangka waktu tertentu dimasa yang akan datang.

b. Waktu (Time)

Yaitu suatu masa yang memisahkan antara pemberian prestasi dengan kontra prestasi yang akan diterima pada masa yang akan datang.

c. Tingkat Resiko (Degree of Risk)

Yaitu suatu tingkat resiko yang akan dihadapi sebagai akibat adanya jangka waktu yang memisahkan antara pemberian prestasi dengan kontra prestasi yang akan diterima kemudian hari. Semakin lama kredit yang 
diberikan semakin tinggi pula tingkat resikonya, karena sejauh masih selalu terdapat unsur ketidaktentuan yang tidak dapat diperhitungkan. Inilah yang menyebabkan timbulnya unsur resiko. Dengan adanya unsur ini maka timbullah jaminan dalam pemberian kredit.

d. Prestasi

Prestasi atau objek kredit itu tidak saja diberikan dalam bentuk uang, tetapi juga dapat berbentuk barang atau jasa.

Jenis kredit berdasarkan ciri dan tujuan penggunaan, Mudrajad Kuncoro, (2002:229), antara lain :

a. Kredit Modal Kerja (KMK)

Adalah fasilitas yang dipergunakan untuk membiayai aktiva lancar atau menggantikan hutang dagang, serta membiayai sementara kegiatan operasional rutin (sehari-hari) perusahaan (Perusahaan jasa, Transportasi, Perhotelan, Rumah Makan dan sebagainya) baik yang bersifat langsung maupun tidak langsung.

b. Kredit Transaksi Khusus

Adalah fasilitas kredit yang hanya sekali pakai yang disetujui untuk suatu tujuan atau beberapa tujuan tertentu.

c. Kredit Tidak Langsung (Kontijen)

Adalah kredit yang tidak memerlukan disposisi dana secara langsung pada saat kredit tersebut disetujui.

d. Kredit Investasi

Adalah fasilitas kredit yang diberikan untuk membantu pembiayaan pemohon dalam memperoleh barang modal selain tanah yang tercermin dalam aktiva tetap perusahaan.

e. Kredit Konsumtif

Adalah kredit yang diberikan untuk membiayai kebutuhan konsumtif yang diperlukan pemohon dan sumber pembayaran kembali kreditnya berasal dari penghasilan / gaji pemohon.

Prinsip-Prinsip Pemberian Kredit

Dasar penilaian kredit yang dipakai di dunia perbankan dikenal dengan prinsip 5C yang terdiri dari :

- Character / Watak

Suatu keyakinan bahwa sifat atau watak dari orang - orang yang diberikan kredit benar - benar dapat dipercaya, hal ini tercermin dari latar belakang debitur baik yang bersifat latar belakang pekerjaan maupun bersifat pribadi seperti cara hidup, gaya hidup yang dianutnya, keadaan keluarga, kebiasaan dan social standingnya.

- Capacity/ Kapasitas

Untuk melihat nasabah dalam kemampuannya dalam bidang bisnis dihubungkan dengan pendidikannya, kemampuan bisnis juga diukur dengan kemampuannya dalam memaahami tentang ketentuan - ketentuan pemerintah. Begitu pula dengan kemampuannya dalam menjalankan usahanya selama ini. Pada akhirnya akan terlihat kemampuannya dalam mengembalikan kredit yang disalurkan.

- Capital / Permodalan

Untuk melihat penggunaan modal apakah efektif, dilihat dari laporan keuangan ( neraca dan laporan laba rugi ) dengan melakukan pengukuran 
seperti segi likuiditas, solvabilitas, rentabilitas dan ukuran lainnya. Capital juga harus dilihat dari sumber mana saja modal yang ada sekarang ini.

- Collateral / Agunan

Merupakan jaminan yang diberikan calon nasabah baik yang bersifat fisik maupun non fisik. Jaminan hendaknya melebihi jumlah kredit yang diberikan, jaminan juga harus diteliti keabsahannya sehingga jika terjadi sesuatu masalah, maka maka jaminan yang dititipkan akan dapat dipergunakan secepat mungkin.

- Condition of Economic / Kondisi Ekonomi

Dalam menilai kredit hendaknya juga dinilai kondisi ekonomi dan politik sekarang dan dimasa yang akan dating sesuai sector masing-masing, serta prospek usaha dari sector yang debitur jalankan. Penilaian prospek bidang usaha yang dibiayai hendaknya benar - benar memiliki prospek yang baik, sehingga kemungkinan kredit tersebut bermasalah relatif kecil.

\section{Prosedur Pemberian Kredit}

Sesuai dengan penjelasan Undang - undang No. 10 tahun 1998 tentang perbankan ditegaskan bahwa kredit yang disalurkan oleh bank mengandung resiko, sehingga dalam pelaksananya bank harus memperhatikan asas - asas perkreditan yang sehat, agar penyaluran kredit dapat dilaksanakan secara konsisten.

Untuk itu setiap bank diharuskan membuat suatu kebijakan perkreditan secara tertulis yang dapat dipergunakan sebagai panduan dalam penyaluran kredit sehari - hari. Pada PT. BPR Rangkiangprosedur pemberian kredit merupakan langkah-langkah atau suatu proses yang harus dilalui dalam pemberian kredit. Setiap langkah atau proses tersebut harus dilakukan secara baik dan berhati - hati agar kredit yang disalurkan dapat berjalan dengan lancar dan kembali tepat waktu, tepat jumlah dan berhasil guna bagi kedua belah pihak yaitu pihak bank dan pihak debitur.

Prosedur pemberian kredit pada PT. Bank Perkreditan Rakyat Rangkiang Aur adalah sebagai berikut :

1. Permohonan Kredit

Tahap pertama dari prosedur pemberian kredit adalah adanya pengajuan surat permohonan dari calon debitur yang diajukan secara tertulis, baik atas observasi lapangan dari Accont Officer ( analis kredit) atau memang atas kehendak calon debitur yang membutuhkan modal untuk pengembangan usahanya dan langsung mendatangi bank.

Surat permohonan kredit tersebut antara lain memuat :

a. Identitas calon debitur

b. Permohonan baru, tambahan, perpanjangan dsb

c. Jumlah modal yang dimohonkan

d. Tujuan penggunaan

e. Sumber pengembalian pinjaman

f. Jangka waktu

g. Suku bunga

h. Agunan jaminan

i. Tandatangan pemohon

Semua dokumen yang disyaratkan harus ditanda tangani secara lengkap dan sesuai dengan keadaan yang sebenarnya. 


\section{Pengumpulan Data}

Setelah permohonan diajukan oleh debitur, pihak bank akan mencatat dalam registrasi khusus yang telah disediakan. Maka langkah selanjutnya yang dilakukan oleh pihak bank adalah melakukan registrasi pada buku permohonan kredit. Bila permohonan tersebut layak untuk diproses, Account Officer akan meminta data pendukung antara lain:

A. Fotocopy kartu keluarga

B. Fotocopy KTP (suami istri)

C. Fotocopy bukti jaminan
a. $\mathrm{PC}$ BPKB + STNK
b. PC Kartu kuning (ditambah bukti iuran 3 bulan terakhir)
c. PC Sertifikat hak milik (tanah)

D. Pas photo $3 \times 4$

E. Surat keterangan lainnya yang berhubungan dengan usaha calon debitur dan surat pendukung atas kepemilikan barang jaminan.

Selain itu juga dilakukan wawancara awal ( wawancara pendahuluan ) yang bertujuan memperoleh informasi sebanyak - banyaknya tentang calon debitur baik usaha, keluarga, kultur masyarakatnya serta informasi lainnya yang terangkum dalam prinsip 5C. Selain itu dalam wawancara awal juga bertujuan memberitahukan bagaimana ketentuan perkreditan pada PT. Bank Perkreditan Rakyat Rangkiang Aur.

3. Survei Lapangan (On The Spot)

Setelah langkah itu dilakukan, pihak bank akan melakukan survei lapangan. Pihak bank yang diwakilkan dengan pejabat yang berwenang dibidangnya akan mendatangi lokasi usaha calon debitur dan melakukan analisa secara langsung. Dalam tahap ini bank juga terkadang melakukan wawancara dengan pihak-pihak lain yang mengetahui karakter dan usaha calon debitur. Termasuk melakukan kunjungan ke lokasi agunan calon debitur untuk mengetahui kebenaran dan nilai agunan, dan penelitian atas kebenaran data - data yang telah diberikan calon debitur sebelumnya.

Hal-hal yang perlu diamati antara lain :

a. Apakah seluruh data yang diberikan telah benar dengan administrasi atau kenyataan yang ada.

b. Seluruh izin-izin dan identitas diri dilihat keasliannya.

c. Tempat usaha debitur apakah dalam status milik sendiri, sewa atau lainnya.

d. Aktivitas usahanya ( sistem pembelian / penjualannya .

e. Pemeriksaan jaminan yang diserahkan ( lokasi, kondisi, jenis, luas, kepemilikan, harga ).

f. Bagaimana keadaan keluarga, lingkungan tempat usaha calon debitur dan mengamati bagaimana prospek usaha calon debitur dimasa yang akan datang.

Sebagai dokumentasi sebaiknya diambil foto mengenai kegiatan usaha dan jaminan yang diserahkan untuk meyakinkan dalam pengambilan keputusan komite kredit. Setelah On The Spot selesai dilakukan, Account 
Officer ( A/O ) membuat laporan kunjungan yang ditandatangani oleh A/O pendamping ( surveyor) dan juga ditandatangani oleh calon debitur.

4. Pembuatan Studi Kelayakan

Setelah melakukan kunjungan kelapangan, kemudian Account Officer sponsor membuat study kelayakan kredit yang berisikan kondisi usaha calon debitur secara keseluruhan yang meliputi berbagai aspek seperti Aspek Keuangan, Aspek Legal, Aspek Teknis, Aspek Pemasaran dan aspek lainnya. Pada Aspek Keuangan, terdapat arus kas keuangan calon debitur dan laporan laba / rugi dari usaha calon debitur.

Dari studi kelayakan ini dapat ditentukan berapa kebutuhan dana calon debitur dan berapa kemampuan cicilan kredit setiap bulannya serta sejauh mana penilaian barang jaminan terhadap fasilitas kredit yang diberikan.

5. Commite Credit

Commite Credit (Kredit komite) adalah suatu tim dalam proses pemberian kredit yang anggotanya pada umumnya terdiri dari Account Officer, Analisa Kredit, Administrasi Kredit, dan Dewan pengambil keputusan yang biasanya pada PT. Bank Perkreditan Rakyat Rangkiang Aur adalah Dewan Direksi. Setelah A/O sponsor menyiapkan study kelayakan kredit maka A/O sponsor mengusulkan akan mengadakan rapat komite, sebelumnya A/O Sponsor harus menyiapkan terlebih dahulu berkas - berkas yang akan dibawa ke dalam rapat komite kredit seperti lembaran putusan hasil komite kredit, proposal kredit dan lembaran pendukung lainnya.

Di dalam komite kredit hal - hal yang dibicarakan adalah permohonan kredit ditinjau dari segala aspek. Setiap aspek, anggota komite kredit berhak memberikan pendapatnya sebagai masukan untuk pengambilan keputusan. Komite inilah yang menentukan apakah permohonan calon debitur dapat disetujui atau ditolak. Apabila disetujui maka berkas yang telah dipersiapkan tersebut diberikan kepada bagian Administrasi Kredit agar disiapkan kelengkapan untuk pencairan kredit.

6. Realisasi Kredit

Setelah semua syarat dipenuhi dan rekomendasi disetujui, maka dibuat Surat Perjanjian Kredit serta Surat Pengikatan Jaminan dan surat - surat lainnya yang akan ditandatangani oleh nasabah, bukti kepemilikan jaminan atau agunan diserahkan kepada pihak bank maka kredit baru dapat dicairkan.

7. Administrasi Kredit

Setelah kredit dicairkan, semua berkas-berkas kredit tersebut disimpan dalam suatu file oleh Administrasi Kredit dan dibuatkan Kartu Cicilan pinjaman untuk mengontrol pengembalian kredit oleh debitur. Dan petugas Administrasi Kredit bertanggungjawab atas pembuatan laporan - laporan kredit setiap bulannya.

8. Pengawasan Kredit

Demi kelancaran pengembalian pinjaman tersebut, maka A/O Sponsor harus melakukan monitoring kepada nasabah secara berkala, sehingga setiap permasalahan yang akan timbul dapat segera diketahui dan bisa dengan segera dicari jalan keluarnya.

Dalam pemberian pinjaman hal-hal yang diterapkan adalah: 
a. Pemberian kredit diprioritaskan kepada nasabah tabungan sehingga pihak bank lebih mudah dalam mengontrol pengembaliannya melalui arus kas dan karakter dari nasabah sudah diketahui terlebih dahulu.

b. Pihak bank harus lebih berhati - hati dalam melihat karakter nasabah serta melihat prospek usaha yang akan dibiayai karena tingkat persaingan pasar yang ketat.

c. Dalam pengelolaan pemberian kredit selain menggunakan prinsip 5C harus juga diperhatikan prinsip 3T yaitu Tepat Waktu, Tepat Jumlah, Tepat Guna tanpa mengabaikan prinsip kehati - hatian.

d. Harus dilakukan monitoring secara lanjut dan berkala, sehingga memperkecil resiko kerugian bagi kedua belah pihak.

Upaya PT. Bank Perkreditan Rakyat Rangkiang Aur Dalam Mengatasi Kredit Bermasalah

Setiap kredit yang diberikan tidak semuanya akan mengalami keberhasilan ada sebahagian kredit yang mengalami masalah yang disebabkan karena kesalahan petugas dalam menilai calon debitur, faktor debitur itu sendiri dan faktor bencana alam.

Adapun upaya - upaya yang dilakukan oleh PT. Bank Perkreditan Rakyat Rangkiang Aur dalam mengatasi kredit bermasalah adalah sebagai berikut :

a. Untuk menjaga kelancaran cicilan kredit tiap bulannya, pihak PT. Bank Perkreditan Rakyat Rangkiang Aur menyarankan agar calon debitur membuka rekening tabungan yang dapat dijemput oleh petugas Bank setiap hari atau minimal 1 kali seminggu dimana bertujuan untuk meringankan kewajiban calon debitur seriap bulannya. Sedangkan keuntungan dari pihak Bank dengan dikunjungi 1 kali dalam seminggu dan melihat fluktuasi tabungan debitur secara langsung merupakan salah satu teknis sarana pengawasan untuk mengetahui kendala yang dihadapi oleh calon debitur.

b. Untuk debitur yang telah menunggak 1 bulan hingga 3 bulan, pihak PT. Bank Perkreditan Rakyat Rangkiang Aur khusus bagian kredit melakukan penagihan kelokasi usaha yang bersangkutan dengan membawa surat tagihan dan surat peringatan yang telah disiapkan oleh bagian Administrasi kredit.

c. Apabila dalam penagihan tersebut terdapat nasabah yang memiliki keinginan untuk membayar namun karena usahanya mengalami penurunan sehingga tidak dapat mencukupi cicilan kredit sebelumnya, maka pihak Bank harus melakukan langkah-langkah yang lebih konkrit seperti :

1. Rescheduling, yaitu dengan cara memberikan keringanan berupa merubah jangka waktu, jumlah angsuran dan berbagai bimbingan dari pihak bank dengan dasar debitur harus cooperative, beritikad baik, prospek usaha kedepan baik dan mempunyai dana yang cukup.

2. Reconditioning, yaitu dengan cara memberikan keringanan suku bunga, penundaan angsuran.

3. Restructuring, yaitu cara penyelamatan seperti Rescheduling dan Reconditioning tetapi disertai dengan restrukturisasi permodalan, yaitu dengan menambah modal baru, jumlah kredit, bidang usaha, lokasi usaha dengan dasar debitur harus cooperative, beritikad baik, prospek usaha kedepan baik. 
Apabila hal ini tersebut telah diupayakan dan tidak ada lagi kemungkinan untuk pengembalian kredit maka PT. Bank Perkreditan Rakyat Rangkiang Aur melakukan eksekusi terhadap barang jaminan yang nantinya akan dijual untuk menutupi seluruh kewajiban debitur baik pihak intern bank maupun dengan bantuan pihak ketiga (team penyelsaian kredit bermasalah termasuk didalamnya aparat keamanan).

\section{PENUTUP}

Bank merupakan lembaga yang sangat berperan aktif dalam pertumbuhan perekonomian secara umum. Sebagai lembaga intermediasi antara pihak yang mempunyai dana dan pihak yang membutuhkan dana, bank mempunyai fungsi utama antara lain : Bank sebagai lembaga yang menghimpun dana masyarakat dalam bentuk simpanan, bank sebagai lembaga yang menyalurkan dana ke masyarakat dalam bentuk kredit, bank sebagai lembaga yang melancarkan transaksi perdagangan dan peredaran uang.

Peningkatan peranan perbankan sangat diperlukan untuk meningkatkan volume usaha rill yang dapat mendorong pertumbuhan ekonomi dan dapat meningkatkan kesejahteraan masyarakat. PT. BPR Rangkiang Aur adalah lembaga yang berkompeten untuk mewujudkan peningkatan pertumbuhan perekonomian khususnya masyarakat dalam strata menengah ke bawah. Terbukti dengan peningkatan volume usaha, penyaluran di bidang kredit dan kualitas dari kredit yang disalurkan.

\section{DAFTAR PUSTAKA}

Afriyeni, A. (2019). Mekanisme Transaksi Dan Sistem Perhitungan Bunga Kredit Usaha Mikro Kecil Dan Menengah (UMKM) Pada PT. Pegadaian (Persero) Cabang Ulak Karang. https://doi.org/10.17605/OSF.IO/WB2E6

Alanshari, F., \& Marlius, D. (2018). Prosedur Pemberian Kredit KPR Pada PT. Bank Tabungan Negara (Persero) TBK Cabang Pembantu Bukittinggi. https://doi.org/10.31227/osf.io/rsfhc

Amelia, L., \& Marlius, D. (2018). Pengendalian Kredit Dalam Upaya Menciptakan Bank Yang Sehat Pada PT. Bank Pembangunan Daerah Sumatera Barat Cabang Utama Padang. https://doi.org/10.31227/osf.io/kpc64

Andriani, B., \& Susanto, R. (2019). Pengawasan Kredit PT. Bank Perkreditan Rakyat (BPR) Ophir Pasaman Barat. https://doi.org/10.31219/osf.io/aunvc

Baiya, \& Fernos, J. (2019). Analisis Faktor-Faktor Penyebab Kredit Macet Pada Bank Nagari Cabang Siteba. https://doi.org/10.31227/osf.io/4xuks 
Bank Perkreditan Rakyat Rangkiang Aur. (2007). "sejarah Berdirinya, Legalitas, Misi dan Visi, Struktur Organisasi dan Job description”, PT. BPR Rangkiang Aur.

Darmawanto, \& Fernos, J. (2019). Prosedur Pemberian Kredit Pada Bank Nagari Cabang Sijunjung. https://doi.org/10.31227/osf.io/psqfy

Dendawijaya, Lukman, (2008), “Manajemen Perbankan”, Gramedia Indonesia , Jakarta.

Dunil. Z. (2002). "Bank Auditing Risk Based Audit - Kredit yang diberikan", Edisi Pertama, Jakarta.

Febriansyah, I., \& Afriyeni, A. (2019). Penyelesaian Kredit Bermasalah PT. Bank Pembangunan Daerah (BPD) Sumbar Cabang Alahan Panjang Kabupaten Solok. https://doi.org/10.31219/osf.io/vutmj

Firmansyah, A., \& Fernos, J. (2019). Analisis Kredit Bermasalah Dilihat Dari Standar Non Performing Loan (NPL) Pada PT. Bank Perkreditan Rakyat (BPR) Prima Mulia Anugrah Cabang Padang. https://doi.org/10.31227/osf.io/gcj94

Ikbal, M., \& Marlius, D. (2017). Pengaruh Jumlah Taksiran Dan Uang Pinjaman Terhadap Laba Bersih Pada PT. Pegadaian (UPC) Gurun Laweh. https://doi.org/10.31227/osf.io/uch4a

Kasmir, (2000), “Manajemen Perbankan”, Edisi Pertama, PT Raja Grafindo Persada, Jakarta.

Mudrajad Kuncoro dan Suharjono, (2002), "Manajemen Perbankan Teori dan Aplikasi”. Edisi keempat, BPFE, Yogyakarta.

Orlando, A., \& Susanto, R. (2019). Mekanisme Pencairan Kredit Usaha Rakyat Pada PT. Bank Rakyat Indonesia Unit Lubuk Buaya. https://doi.org/10.31219/osf.io/zuv2y

Pratama, D., \& Fernos, J. (2019). Prosedur Pelaksanaan Kredit Usaha Rakyat (KUR) Pada PT. Bank Nagari Cabang Padang. https://doi.org/10.31227/osf.io/ag68j

R., \& Afriyeni, A. (2019). Mekanisme Transaksi Dan Sistem Perhitungan Bunga Kredit Usaha Mikro Kecil Dan Menengah (UMKM) Pada PT. Pegadaian (Persero) Cabang Ulak Karang. https://doi.org/10.31219/osf.io/rqneu

Rivai. Veithzal, (2006), “Credit Management Handbook”, Edisi Pertama, PT RajaGrafindo Persada, Jakarta. 
Sinungan. Muchdarsyah, (1984), "Dasar-dasar dan Teknik Manajemen Kredit". Bina Aksara, Jakarta.

Thomas Suyatno dkk, (1995), “Dasar-dasar Perkreditan”, Edisi Keempat, PT. Gramadia Pustaka Utama, Jakarta.

Undang-undang Republik Indonesia Nomor 7 Tahun 1992 jo Nomor 10 Tahun 1998, “Tentang Perbankan”, Sinar Grafika, Jakarta, 2002,

Widayati, R. (2019). Penyelesaian Kredit Bermasalah Pada PT. Bank Perkreditan Rakyat (BPR) Nagari Kasang. https://doi.org/10.17605/OSF.IO/D4MF3

Widayati, R. (2019). Pelaksanaan Prinsip Kehati-Hatian Dalam Pemberian Kredit Konsumtif Pada Bank Nagari Cabang Siteba. https://doi.org/10.17605/OSF.IO/FZVXR

Widayati, R. (2019). Aktivitas Pemberian Kredit Komersil Pada Bank Nagari Cabang Sijunjung. https://doi.org/10.17605/OSF.IO/QTVZ9

Widayati, R. (2019). Pelaksanaan Kredit Pada Bank Perkreditan Rakyat LPN Pasar Baru Durian Sawahlunto. https://doi.org/10.17605/OSF.IO/5HPAB

Widayati, R. (2019). Upaya Penanganan Kredit Bermasalah Pada Bank Nagari Cabang Utama Padang. https://doi.org/10.17605/OSF.IO/YJ3KN

Widayati, R. (2019). Aktivitas Pemberian Kredit Usaha Pada PT. Bank Perkreditan Rakyat Batang Kapas. https://doi.org/10.17605/OSF.IO/EDPN4

Yasman, R., \& Afriyeni, A. (2019). Prosedur Pemberian Kredit Pada PT. Bank Pekreditan Rakyat (BPR) Jorong Kampung Tangah (JKT) Pariaman Cabang Padang. https://doi.org/10.31219/osf.io/c5ufr 